\title{
FAKTOR-FAKTOR YANG MEMPENGARUHI KEPERCAYAAN DIRI SISWA KELAS VIII DALAM MENYELESAIKAN MASALAH MATEMATIKA PADA MODEL PMRI
}

\author{
Ratri Rahayu \\ Pendidikan Guru Sekolah Dasar \\ FKIP Universitas Muria Kudus \\ Email: ratri.rahayu@umk.ac.id
}

\begin{abstract}
Abstrak
Penelitian ini bertujuan untuk menganalisis faktor-faktor yang mempengaruhi kepercayaan diri siswa kelas VIII dalam menyelesaikan masalah matematika pada model PMRI (Pendidikan Matematika Realistik Indonesia). Penelitian ini dilaksanakan di SMP Negeri 1 Pecangaan pada tahun pelajaran 2013/2014 dan melibatkan 139 siswa yang dipertimbangkan dari total populasi 218 siswa kelas VIII secara purposive sampling. Instrumen penelitian yang digunakan adalah 5 jenis skala: percaya diri, fleksibilitas, mengapresiasi peranan matematika, menghargai aplikasi matematika, dan refleksi cara berpikir. Data dianalisis dengan analisis regresi. Hasil penelitian menunjukkan: (1) fleksibilitas, mengapresiasi peranan matematika, menghargai aplikasi matematika, dan refleksi cara berpikir secara bersama-sama berpengaruh terhadap kepercayaan diri siswa kelas VIII dalam menyelesaikan masalah matematika sebesar 22\%; (2) mengapresiasi peranan matematika berpengaruh terhadap kepercayaan diri sebesar 31,3\%; (3) menghargai aplikasi matematika berpengaruh terhadap kepercayaan diri sebesar $22,8 \%$.
\end{abstract}

Kata kunci: percaya diri, PMRI

\begin{abstract}
The purpose of this research is to analyze the factors that affect the self-confidence of the $8^{\text {th }}$ grade students in solving mathematical problems on PMRI (Pendidikan Matematika Realistik Indonesia) learning model. The research was conducted in SMP Negeri 1 Pecangaan year 2013/2014 and involving 139 students whom are in considered from the total population is 218 $8^{\text {th }}$ grade students by purposive sampling. The research instruments used were 5 types of scaleself-confidence, flexibility, appreciate the role of mathematics, appreciate the applications of mathematics, and a reflection of the way of thinking. Data were analyzed with regression analysis. The results showed: (1) flexibility, appreciate the role of mathematics, appreciate the applications of mathematics, and a reflection of the way of thinking together affect self confidence of $8^{\text {th }}$ grade students in solving mathematical problems at 22\%; (2) appreciate the role of mathematics influenced the self-confidence at 31.3\%; (3) the application of mathematics to appreciate affect the self-confidence at $22.8 \%$.
\end{abstract}




\section{PENDAHULUAN}

Tujuan mata pelajaran matematika nomor 5 menurut Depdiknas (2006) untuk semua jenjang pendidikan dasar dan menengah adalah agar siswa mampu memiliki sikap menghargai kegunaan matematika dalam kehidupan, yaitu rasa ingin tahu, perhatian, dan minat dalam mempelajari matematika, serta sikap ulet dan percaya diri dalam pemecahan masalah. Tujuan tersebut menunjukkan bahwa pembelajaran matematika tidak hanya bertujuan mengembangkan siswa pada ranah kognitif saja, akan tetapi juga bertujuan meningkatkan ranah afektif. Hasil penelitian Joseph (2011) menyimpulkan bahwa di masa depan assesmen matematika tidak harus hanya mengandalkan pada analisis tes tertulis tetapi analisis peningkatan afektif siswa juga perlu dilakukan. NCTM (1989) menyatakan bahwa sikap siswa dalam menghadapi matematika dan keyakinannya dapat mempengaruhi prestasi mereka dalam matematika.

Percaya diri berpengaruh secara langsung terhadap kemampuan pemecahan masalah matematika sebesar 26,4\% (Rahayu dan Kartono, 2014). Hal ini menunjukkan kepercayaan diri merupakan domain afektif yang berperan penting dalam pembelajaran matematika. Menurut hasil penelitian Gregg (2005) diketahui siswa lebih menyukai pembelajaran yang mengacu pada penggalian pengetahuan karena lebih meyakinkan mereka arti belajar matematika. Kepercayaan siswa memberi kekuatan yang dapat mempengaruhi pada penilaian kemampuan siswa dan kesediaan untuk mengerjakan tugas. Siswa diharapkan memiliki kecenderungan memandang matematika sebagai sesuatu yang dapat dipahami, merasakan matematika sesuatu berguna, meyakini usaha yang tekun dan ulet dalam mempelajari matematika akan membuahkan hasil, dan melakukan perbuatan sebagai pelajar yang efektif (Kilpatrick, Swafford \& Findel, 2001).

Rasa percaya diri siswa dalam PMRI ditunjukkan ketika siswa tidak merasa takut mengikuti pelajaran, optimis mampu menyelesaikan soal pemecahan masalah, berani bertanya kepada guru jika ada hal belum dipahami oleh siswa, dan berani menyampaikan pendapat. Hal ini sesuai dengan karakteristik pembelajaran matematika realistik menurut Bakker (2004) yaitu terpusat pada siswa sehingga mereka secara percaya diri terlibat secara aktif diskusi kelas sikapnya setuju atau tidak setuju dengan solusi temannya, menanyakan alternatif pemecahan masalah, dan merefleksikan solusi-solusi itu. Dengan adanya rasa percaya diri, maka siswa akan lebih termotivasi dan menyukai untuk belajar matematika. Oleh sebab itu, rasa percaya diri perlu dimiliki dan dikembangkan oleh setiap siswa. 
Hasil penelitian Trends in International Mathematics and Science Study (TIMSS) tahun 2011 menggolongkan kemampuan matematika siswa SMP di Indonesia pada kategori rendah yaitu berada di urutan 38 dari 42 negara (Mullis, et al, 2012). Masalah ini perlu menjadi sorotan dari semua pihak karena hasil ini menunjukkan pada dunia internasional bahwa kualitas pendidikan di Indonesia terutama pada mata pelajaran matematika masih rendah.

Masalah rendahnya kemampuan siswa pada mata pelajaran matematika tidak hanya terlihat dari hasil TIMSS 2011, tetapi juga terjadi di semua satuan pendidikan salah satunya di tingkat sekolah menengah pertama. Hasil wawancara dengan guru matematika di SMP Negeri 1 Pecangaan menunjukkan sebagian besar siswa cenderung mengalami kesulitan ketika memasuki materi bangun ruang. Siswa cenderung mengalami kesulitan ketika menyelesaikan soal yang berkaitan dengan soal cerita materi kubus dan balok yang menuntut untuk berpikir tingkat tinggi pada aspek pemecahan masalah. Kesulitan ini salah satunya disebabkan oleh rendahnya kepercayaan diri siswa. Oleh karena itu perlu dilaksanakan penelitian yang mengivestigasi faktor-faktor yang mempengaruhi kepercayaan diri siswa dalam menyelesaikan masalah sehingga hal yang menjadi akar masalah sebenarnya dapat diatasi.
Menurut Aydin, et al (2007), banyak siswa mengalami kesulitan dan menunjukkan kinerja yang buruk dalam kelas geometri baik pada sekolah menengah maupun sekolah tinggi. Solusi dari permasalahan tersebut salah satunya dengan melakukan perubahan dalam pembelajaran dan mencari strategi yang cocok supaya dapat meningkatkan kemampuan pemecahan masalah siswa. Perubahan tersebut dapat dilakukan dengan cara meningkatkan ranah afektif siswa dalam pembelajaran matematika. Tidak hanya kemampuan kognitif siswa, faktor afektif juga mempunyai pengaruh besar terhadap kemampuan pemecahan masalah siswa (Furinghetti dan Morselli, 2009; Caballero et al, 2011).

Inovasi pembelajaran matematika dilakukan dengan cara memilih model pembelajaran matematika PMRI yang dapat meningkatkan kepercayaan diri siswa dalam belajar matematika sehingga pada akhirnya akan meningkatkan pula kemampuan pemecahan masalahnya. Salah satu keunggulan pendekatan PMRI sebagaimana yang dikemukakan Wijaya (2012: 20) adalah menekankan learning by doing, sesuai dengan konsep dasar pembelajaran matematika realistik yang diutarakan Freudental (Van Den Heuvel-Panhuizen: 1998) yaitu “...mathematics as a human activity...".

Berdasar latar belakang di atas, maka dalam penelitian ini permasalahan yang 
diungkapkan adalah faktor-faktor apa saja yang berpengaruh terhadap kepercayaan diri siswa kelas VIII SMP Negeri 1 Pecangaan dalam menyelesaikan masalah matematika pada pembelajaran model PMRI.

\section{METODE PENELITIAN}

Jenis penelitian ini adalah dengan pendekatan kuantitatif yaitu menggunakan analisis regresi untuk mengetahui faktor-faktor yang berpengaruh terhadap kepercayaan diri siswa kelas VIII SMP Negeri 1 Pecangaan Kabupaten Jepara dalam menyelesaikan masalah pada materi kubus dan balok. Terpilih sampel sebanyak 139 siswa dengan teknik purposive sampling. Variabel terikat dalam penelitian ini adalah kepercayaan diri siswa dalam menyelesaikan masalah. Sedangkan variabel bebas dalam penelitian ini antara lain fleksibel dalam melakukan kerja matematika (bermatematika), melakukan refleksi terhadap cara berpikir dan kinerja pada diri sendiri dalam belajar matematika, menghargai aplikasi matematika, dan mengapresiasi peranan matematika.

Teknik pengumpulan data dilakukan dengan melaksanakan pengisian skala percaya diri, fleksibilitas, mengapresiasi peranan matematika, menghargai aplikasi matematika, dan refleksi cara berpikir ketika dilaksanakannya pembelajaran dengan model PMRI materi kubus dan balok. Sebelum instrumen skala diberikan kepada siswa, terlebih dahulu dilakukan uji coba instrumen skala, kemudian dilakukan analisis tentang validitas dan reliabilitas instrumen. Skala afektif dalam penelitian berupa angket dengan skala Likert 4 level. Setelah skala afektif diisi, langkah selanjutnya yaitu melakukan analisis regresi dengan bantuan SPSS data hasil skala kepercayaan diri siswa dalam menyelesaikan masalah matematika dengan skala fleksibilitas, mengapresiasi peranan matematika, menghargai aplikasi matematika, dan refleksi cara berpikir.

\section{HASIL}

Penelitian ini menggunakan analisis regresi untuk mengetahui faktor-faktor yang mempengaruhi kepercayaan diri siswa pada pembelajaran dengan model PMRI. Sebelum melakukan analisis regresi terlebih dulu melakukan uji asumsi dasar yang harus dipenuhi.

Evaluasi atas Asumsi-asumsi Dasar

\section{Uji Normalitas}

Uji normalitas percaya diri dalam menyelesaikan masalah nilai Signifikansi Kolmogorov-Smirnov (Sig.) sebesar 0,659. Karena 0,659 > 0,05 maka data berasal dari sampel yang berdistribusi normal. Perhitungan selengkapnya dapat dilihat pada Tabel 1 berikut. 
Tabel 1 Uji Normalitas Variabel Percaya Diri dalam Menyelesaikan Masalah

\section{One-Sample Kolmogorov-Smirnov Test}

\begin{tabular}{llr}
\hline & & \multicolumn{1}{c}{$\mathrm{Y}$} \\
\hline $\mathrm{N}$ & & 139 \\
Normal Parameters $^{\mathrm{a}}$ & Mean & 21.5252 \\
& Std. Deviation & 4.29413 \\
Most Extreme & Absolute & .062 \\
Differences & Positive & .060 \\
& Negative & -.062 \\
Kolmogorov-Smirnov Z & .731 \\
Asymp. Sig. (2-tailed) & .659 \\
\hline
\end{tabular}

a. Test distribution is Normal.

\section{Uji Multikolinearitas}

Uji multikolinearitas bertujuan untuk menguji apakah terdapat korelasi yang tinggi antara variabel-variabel bebas regresi linear ganda. Tabel 2 merupakan output SPSS untuk menguji multikolinearitas.

Tabel 2 Uji Multikolinearitas

\section{Coefficients $^{\mathrm{a}}$}

\begin{tabular}{|c|c|c|c|}
\hline \multirow{2}{*}{\multicolumn{2}{|c|}{ Model }} & \multicolumn{2}{|c|}{ Collinearity Statistics } \\
\hline & & Tolerance & VIF \\
\hline \multirow[t]{4}{*}{1} & $\mathrm{X} 3$ & .860 & 1.162 \\
\hline & $\mathrm{X} 1$ & .775 & 1.290 \\
\hline & $\mathrm{X} 4$ & .907 & 1.102 \\
\hline & $\mathrm{X} 2$ & .775 & 1.290 \\
\hline
\end{tabular}

a. Dependent Variable: $\mathrm{Y}$

Berdasar tabel di atas diperoleh nilai VIF berada di sekitar angka 1, artinya tidak terjadi multikolinearitas antara varibel bebas pada regresi linear ganda.

3. Uji Autokorelasi

Berdasar hasil output SPSS pada Tabel 3 diperoleh nilai DW $=1,893$ masih berada interval -2 sampai 2 berarti tidak terjadi autokorelasi. Hal ini menunjukkan tidak ada adanya korelasi antara kesalahan pengganggu pada pengamatan yang satu dengan pengamatan sebelumnya. Output SPSS mengenai uji autokorelasi dapat dilihat pada Tabel 3 di bawah ini.

Tabel 3 Uji Autokorelasi

Model Summary ${ }^{b}$

\begin{tabular}{lll}
\hline Model & Durbin-Watson & \\
\hline 1 & & $1.863^{\mathrm{a}}$ \\
\hline
\end{tabular}

a. Predictors: (Constant), X1, X2, X3, X4

b. Dependent Variable: Y

\section{Uji Heteroskedastis}

Berdasar hasil output SPSS pada Gambar 1 terlihat tidak ada pola yang jelas serta titiktitik menyebar di atas dan di bawah angka 0 pada sumbu y. Artinya tidak terjadi heteroskedastis sehingga tidak terjadi ketidaksamaan varians dari residual dari satu pengamatan ke pengamatan yang lain.

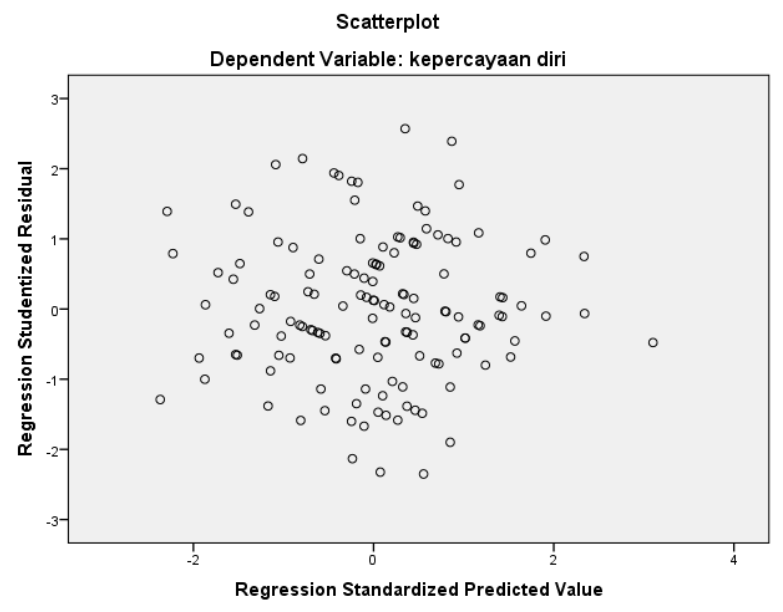

Gambar 1 Grafik Scatterplot Variabel Percaya Diri 


\section{Analisis Data}

Pada analisis data dibagi menjadi dua bagian, yaitu analisis regresi dan analisis korelasi. Pada bagian analisis regresi dibagi menjadi dua bagian. Pertama, melihat pengaruh secara gabungan dan kedua, melihat pengaruh secara parsial.

1. Pengaruh fleksibel dalam mencari ide dan mencoba berbagai alternatif jawaban, refleksi cara berpikir dan kinerja pada diri sendiri, menghargai aplikasi matematika dalam bidang lain dan kehidupan seharihari, serta mengapresiasi /menghargai peranan pelajaran matematika dalam bidang lain dan kehidupan sehari-hari secara gabungan terhadap percaya diri dalam menyelesaikan masalah kita akan melihat hasil perhitungan dalam model summary, khususnya angka $\mathrm{R}$ square pada Tabel 4 di bawah ini.

Tabel 4 Output SPSS mengenai Analisis Regresi Linear Ganda

\begin{tabular}{|c|c|c|c|c|c|}
\hline \multicolumn{6}{|c|}{ Model Summary ${ }^{\mathrm{D}}$} \\
\hline Model & $\mathrm{R}$ & $\begin{array}{c}\mathrm{R} \\
\text { Square }\end{array}$ & $\begin{array}{c}\text { Adjusted } \\
\text { R } \\
\text { Square }\end{array}$ & $\begin{array}{c}\text { Std. } \\
\text { Error of } \\
\text { the } \\
\text { Estimate }\end{array}$ & $\begin{array}{l}\text { Durbin- } \\
\text { Watson }\end{array}$ \\
\hline 1 &, $469^{\mathrm{a}}$ & 220 & , 196 & 3,84952 & 1,863 \\
\hline $\begin{array}{l}\text { a. Prec } \\
\text { perana }\end{array}$ & $1 \mathrm{KK}$ & $\begin{array}{l}\text { onstar } \\
\text { engha }\end{array}$ & $\begin{array}{l}\text { refleks } \\
\text { i aplika } \\
\end{array}$ & $\begin{array}{l}\text { nengapre } \\
\text { ntk, fleks }\end{array}$ & $\begin{array}{l}\text { asi } \\
\text { ilitas }\end{array}$ \\
\hline
\end{tabular}

Berdasar tabel di atas diperoleh nilai $\mathrm{R}$ square $=0,220$. Hal ini berarti besar pengaruh fleksibel dalam mencari ide dan mencoba berbagai alternatif jawaban, refleksi cara berpikir dan kinerja pada diri sendiri, menghargai aplikasi matematika dalam bidang lain dan kehidupan seharihari, serta mengapresiasi /menghargai peranan pelajaran matematika dalam bidang lain dan kehidupan sehari-hari secara gabungan terhadap percaya diri dalam menyelesaikan masalah secara gabungan $=$ $22 \%$ dan sisanya $78 \%$ dipengaruhi oleh faktor lain di luar model ini.

Untuk mengetahui apakah model regresi di atas sudah linear atau belum perlu diuji linearitas dari model regresi. Tabel 5 merupakan output SPSS untuk menguji linearitas.

Tabel 5 Output SPSS mengenai Uji Linearitas Model Regresi Linear Ganda

\begin{tabular}{|c|c|c|c|c|c|c|}
\hline \multicolumn{7}{|c|}{ ANOVA $^{a}$} \\
\hline \multicolumn{2}{|c|}{ Model } & Sum of & df & Mean & $\mathrm{F}$ & Sig. \\
\hline \multirow{3}{*}{1} & Regression & 558,941 & 4 & 139,735 & 9,430 & $000^{6}$ \\
\hline & Residual & 1985,721 & 134 & 14,819 & & \\
\hline & Total & 2544,662 & 138 & & & \\
\hline \multicolumn{7}{|c|}{ a. Dependent Variable: percaya diri } \\
\hline & $\begin{array}{l}\text { edictors } \\
\text { lan mtk. }\end{array}$ & $\begin{array}{l}\text { nstan } \\
\text { nghars }\end{array}$ & ek & $\begin{array}{c}\mathrm{me} \\
\mathrm{mt}\end{array}$ & sibili & \\
\hline
\end{tabular}

Hipotesisnya berbunyi sebagai berikut. $\mathrm{H} 0=$ tidak ada hubungan linear antara X1, X2, X3, X4 terhadap Y. $\mathrm{H} 1=$ ada hubungan linear antara $\mathrm{X} 1, \mathrm{X} 2$, X3, X4 terhadap Y.

Berdasar Tabel 5 diperoleh nilai signifikan $0.000<0.05$ sehingga $\mathrm{H} 0$ ditolak dan $\mathrm{H} 1$ diterima. Artinya ada hubungan linear 
antara X1, X2, X3, X4 terhadap Y. Dengan kata lain fleksibel dalam mencari ide dan mencoba berbagai alternatif jawaban, refleksi cara berpikir dan kinerja pada diri sendiri, menghargai aplikasi matematika dalam bidang lain dan kehidupan seharihari, serta mengapresiasi /menghargai peranan pelajaran matematika dalam bidang lain dan kehidupan sehari-hari secara gabungan mempengaruhi percaya diri dalam menyelesaikan masalah dengan besar pengaruh $22 \%$ dan sisanya $78 \%$ dipengaruhi oleh faktor lain di luar model ini.

2. Pengaruh fleksibel dalam mencari ide dan mencoba berbagai alternatif jawaban, refleksi cara berpikir dan kinerja pada diri sendiri, menghargai aplikasi matematika dalam bidang lain dan kehidupan seharihari, serta mengapresiasi /menghargai peranan pelajaran matematika dalam bidang lain dan kehidupan sehari-hari terhadap percaya diri dalam menyelesaikan masalah secara parsial.

Untuk melihat pengaruh secara parsial, dilihat nilai signifikan dari masingmasing variabel, sedangkan untuk melihat besar pengaruh dilihat dari angka Beta pada Tabel 6 di bawah ini.
Tabel 6 Output SPSS mengenai Uji Pengaruh secara Parsial

\begin{tabular}{|c|c|c|c|c|c|}
\hline \multirow{3}{*}{ Model } & \multicolumn{3}{|c|}{ Coefficients $^{a}$} & \multirow{3}{*}{$t$} & \multirow{3}{*}{ Sig } \\
\hline & \multicolumn{2}{|c|}{$\begin{array}{l}\text { Unstandardiz } \\
\text { ed } \\
\text { Coefficients }\end{array}$} & \multirow{2}{*}{$\begin{array}{c}\text { Standardiz } \\
\text { ed } \\
\text { Coefficient } \\
\text { s } \\
\text { Beta }\end{array}$} & & \\
\hline & $B$ & $\begin{array}{l}\text { Std. } \\
\text { Error }\end{array}$ & & & \\
\hline (Constant) & 8,927 & 2,421 & & $\begin{array}{r}3,68 \\
7\end{array}$ & $\begin{array}{r}, 00 \\
0\end{array}$ \\
\hline fleksibilitas & 159 & , 156 & ,088 & $\begin{array}{r}1,01 \\
7\end{array}$ & $\begin{array}{r}31 \\
1\end{array}$ \\
\hline${ }_{1}$ refleksi &,- 051 & , 142 &,- 029 & 356 & $\begin{array}{r}72 \\
2\end{array}$ \\
\hline $\begin{array}{l}\text { menghargai } \\
\text { aplikasi mtk }\end{array}$ & 401, & 145, & 228, & $\begin{array}{r}2,77 \\
1 \\
\end{array}$ & $\begin{array}{r}00 \\
6 \\
\end{array}$ \\
\hline $\begin{array}{l}\text { mengapresi } \\
\text { asi peranan } \\
\mathrm{mtk}\end{array}$ & 439, & 121, & 313, & $\begin{array}{r}3,61 \\
5\end{array}$ & $\begin{array}{r}, 00 \\
0\end{array}$ \\
\hline
\end{tabular}

a. Dependent Variable: percaya diri

a. Hubungan antara fleksibel dalam mencari ide dan mencoba berbagai alternatif jawaban dan percaya diri dalam menyelesaikan masalah

Hipotesisnya berbunyi sebagai berikut.

$\mathrm{HO}=$ tidak ada hubungan linear antara fleksibel dalam mencari ide dan mencoba berbagai alternatif jawaban dan percaya diri dalam menyelesaikan masalah

H1 = ada hubungan linear fleksibel dalam mencari ide dan mencoba berbagai alternatif jawaban dan percaya diri dalam menyelesaikan masalah

Karena diperoleh nilai signifikan 0,311 > 0,05 maka H0 diterima dan H1 ditolak. Hal ini berarti tidak ada hubungan linear antara fleksibel dalam mencari ide dan 
mencoba berbagai alternatif jawaban dan percaya diri dalam menyelesaikan masalah. Besar pengaruh fleksibel dalam mencari ide dan mencoba berbagai alternatif jawaban dan percaya diri dalam menyelesaikan masalah $=8.8 \%$ dianggap tidak signifikan.

b. Hubungan antara mengapresiasi /menghargai peranan pelajaran matematika dalam bidang lain dan kehidupan sehari-hari dan percaya diri dalam menyelesaikan masalah

Hipotesisnya berbunyi sebagai berikut. $\mathrm{H} 0$ = tidak ada hubungan linear antara mengapresiasi /menghargai peranan pelajaran matematika dalam bidang lain dan kehidupan sehari-hari dan percaya diri dalam menyelesaikan masalah.

$\mathrm{H} 1=$ ada hubungan linear mengapresiasi /menghargai peranan pelajaran matematika dalam bidang lain dan kehidupan sehari-hari dan percaya diri dalam menyelesaikan masalah.

Karena diperoleh nilai signifikan $0.000<$ 0.05 maka H0 ditolak dan H1 diterima. Hal ini berarti ada hubungan linear antara mengapresiasi /menghargai peranan pelajaran matematika dalam bidang lain dan kehidupan sehari-hari dan percaya diri dalam menyelesaikan masalah. Besar pengaruh mengapresiasi /menghargai peranan pelajaran matematika dalam bidang lain dan kehidupan sehari-hari terhadap percaya diri dalam menyelesaikan masalah = $31,3 \%$ dianggap signifikan dan sisanya $68,7 \%$ dipengaruhi oleh faktor lain di luar penelitian.

c. Hubungan antara menghargai aplikasi matematika dalam bidang lain dan kehidupan sehari-hari dan percaya diri dalam menyelesaikan masalah

Hipotesisnya berbunyi sebagai berikut. $\mathrm{HO}=$ tidak ada hubungan linear antara menghargai aplikasi matematika dalam bidang lain dan kehidupan sehari-hari dan percaya diri dalam menyelesaikan masalah.

H1 = ada hubungan linear menghargai aplikasi matematika dalam bidang lain dan kehidupan sehari-hari dan percaya diri dalam menyelesaikan masalah.

Karena diperoleh nilai signifikan $0.006<$ 0.05 maka H0 ditolak dan H1 diterima. Hal ini berarti ada hubungan linear antara menghargai aplikasi matematika dalam bidang lain dan kehidupan seharihari dan percaya diri dalam menyelesaikan masalah. Besar pengaruh menghargai aplikasi matematika dalam bidang lain dan kehidupan sehari-hari 
terhadap percaya diri dalam menyelesaikan masalah $=22,8 \%$ dianggap signifikan dan sisanya $77,2 \%$ dipengaruhi oleh faktor lain di luar penelitian.

d. Hubungan antara refleksi cara berpikir dan kinerja pada diri sendiri dan percaya diri dalam menyelesaikan masalah

Hipotesisnya berbunyi sebagai berikut. HO = tidak ada hubungan linear antara refleksi cara berpikir dan kinerja pada diri sendiri dan percaya diri dalam menyelesaikan masalah $\mathrm{H} 1$ = ada hubungan linear refleksi cara berpikir dan kinerja pada diri sendiri dan percaya diri dalam menyelesaikan masalah

Karena diperoleh nilai signifikan 0,722> 0,05 maka H0 diterima dan $\mathrm{H} 1$ ditolak. Hal ini berarti tidak ada hubungan linear antara refleksi cara berpikir dan kinerja pada diri sendiri dan percaya diri dalam menyelesaikan masalah. Besar pengaruh refleksi cara berpikir dan kinerja pada diri sendiri secara negatif terhadap percaya diri dalam menyelesaikan masalah $=2,9 \%$ dianggap tidak signifikan.

Gambar 2 menunjukkan bagaimana komponen afektif yang mempengaruhi kepercayaan diri siswa kelas VIII dalam menyelesaikan masalah.

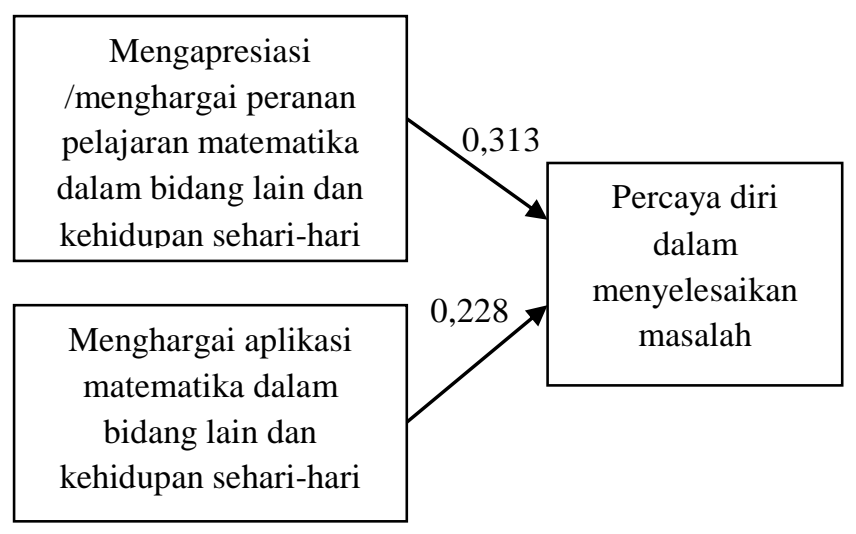

Gambar 2. Diagram Jalur Faktor-faktor yang mempengaruhi Kepercayaan Diri Siswa

\section{PEMBAHASAN}

Mengapresiasi/menghargai peranan pelajaran matematika dalam bidang lain dan kehidupan sehari-hari terhadap percaya diri berpengaruh sebesar 0,31,3\%. Artinya, jika semakin siswa mengapresiasi peranan pelajaran matematika meningkat maka akan meningkatkan rasa percaya diri yang berdampak pada peningkatan kemampuan pemecahan masalah. Pembelajaran matematika dengan model PMRI memfasilitasi siswa untuk berpikir kritis, berdiskusi dan berani berpendapat sehingga mampu melatih siswa lancar berbicara dalam keseharian. Hal ini tentunya membuat siswa merasa percaya diri dalam menyelesaikan soal pemecahan kontekstual.

Menghargai aplikasi matematika dalam bidang lain-lain kehidupan sehari-hari berpengaruh terhadap percaya diri sebesar 22,8\%. Menghargai aplikasi matematika tidak 
tumbuh secara instan akan tetapi keyakinan dalam diri siswa tersebut harus ditumbuhkan sejak lama. Keyakinan bahwa matematika dapat membantu memecahkan persoalan sehari-hari dapat ditumbuhkan dengan cara menggali pengetahuan melalui permasalahan kontekstual sesuai dengan karakter phenomenological exploration pada PMRI.

Pembelajaran dengan penyajian masalah kontekstual akan mudah dipahami sehingga menimbulkan rasa percaya diri siswa untuk dapat menyelesaikan soal pemecahan masalah.

\section{SIMPULAN}

Berdasarkan uji ANAVA diperoleh fleksibilitas, mengapresiasi peranan matematika, menghargai aplikasi matematika, dan refleksi cara berpikir secara bersama-sama berpengaruh terhadap kepercayaan diri siswa

\section{DAFTAR PUSTAKA}

Aydin, E., Hallat, E., dan Jakubowski, H. 2007. "Reform-based Curriculum and Motivation in Geometry". Eurasia Journal of Mathematics, Sciences \& Technology Education, Volume 4 No. 3. Hal 285-292.

Bakker, A. 2004. Design Research in Statistic Education on Symbolizing and Computer Tools. Amersfoort: Wilco.

Caballero, A., Blanco, L.,Guerrero, E. 2011. "Problem Solving and Emotional Education in Initial Primary Teacher Education". Eurasia Journal of Mathematicsof Mathematics, Science kelas VIII dalam menyelesaikan masalah matematika sebesar $22 \%$.

Selanjutnya dilakukan uji regresi parsial yang menunjukkan hasil bahwa menghargai aplikasi matematika dalam bidang lain dan kehidupan sehari-hari mempengaruhi kepercayaan diri siswa kelas VIII SMP N 1 Pecangaan pada PMRI sebesar 22,8\%. Sedangkan mengapresiasi /menghargai peranan pelajaran matematika dalam bidang lain dan kehidupan sehari-hari berpengaruh secara signifikan sebesar $31,3 \%$ terhadap kepercayaan diri siswa kelas VIII SMP N 1 Pecangaan pada PMRI.

Fleksibilitas dalam mencari ide dan mencoba berbagai alternatif jawaban serta refleksi cara berpikir dan kinerja pada diri sendiri tidak berpengaruh terhadap kepercayaan diri siswa kelas VIII SMP N 1 Pecangaan pada PMRI.

\& Technology Education, 7(4): 281-292.

Depdiknas. 2006. Panduan Penyusunan Kurikulum Tingkat Satuan Pendidikan. Badan Standar Nasional Pendidikan: Jakarta.

Furinghetti, F. \& Morselli, F. 2009.” Every Unsuccessful Problem Solver is Unsuccessful in His or Her Own Way: Affective and Cognitive Factors In Proving”. Springer. Vol.70, pp:71-90.

Gregg, P.A. 2005. "Using Writing as a Vihicle to Assess Mathematical Dispositions". 
Current Issues in Middle Level Education, 11(1): 33-44.

Joseph, Y. 2011. “An Exploratory Study of Primary Two Pupils' Approach Journal of Mathematics Education to Solve Word Problems". Journal of Mathematics Education, 4 (1): 19-30.

Kilpatrick,J.,Swafford,J.,\&Findel,B. 2001. Adding It Up : Helping Children Learn Mathematics". Washington, DC : National Academy - Press.

Mullis, I et al. 2012. TIMSS 2011 International Results in Mathematics. Chesnut Hills: Boston College.

National Council of Teachers of Mathematic (NCTM). 1989. Curriculum and
Evaluation Standards for School Mathematics. Reston VA : Authur.

Rahayu. R dan Kartono. 2014. "The Effect of Mathematical Disposition toward Problem Solving Ability Based On IDEAL Problem Solver". International Journal of Science and Research (IJSR), 3(10): 1315-1318.

Van den Heuvel-Panhuizen, M. 1998. Realistic Mathematics Education. Work in Progress. http://www.fi.uu.nl/en/rme. (diunduh 3 Desember 2015).

Wijaya, A. 2012. Pendidikan Matematika Realistik: Suatu Alternatif Pendekatan Pembelajaran Matematika. Yogyakarta: Graha Ilmu. 